\title{
Modern models of pedagogical education of Great Britain, Canada and the USA
}

\author{
Z. Chernyakova, I. Chystiakova
}

\author{
Sumy State Pedagogical University named after A. S. Makarenko, Ukraine \\ Corresponding author. E-mail: janechernyakova@gmail.com; pedagogyniversitet2017@gmail.com
}

Paper received 27.04.18; Accepted for publication 01.05.18.

\section{http://doi.org/10.31174/SEND-PP2018-164VI68-02}

\begin{abstract}
The article deals with the problem of the development of the pedagogical education in foreign countries. The analysis of modern models of pedagogical education in Great Britain, Canada and the USA is presented in the article. The peculiarities of modern models of pedagogical education are highlighted. The models of Undergraduate teacher training Postgraduate training of teachers, Postgraduate Education, Primary training teachers, Employability classes in the sphere of employment, the Graduate Teaching Program, Registered Teachers Program, Training of teachers based on evaluation, Foreign prepared pedagogical program are defined in Great Britain. The synchronous, consistent models of pedagogical education of Canada are analyzed. The parallel, consistent and alternative models of professional training of future teachers of the USA are examined.
\end{abstract}

Keywords: educational system, pedagogical education, a model, Great Britain, Canada, the USA.

Introduction. The analysis of the growth of the educational systems of developed countries in the last decades of the twentieth and beginning of the 21-st century makes it possible to assert that this stage is the epoch of global education reform at the world level. There is an international unification of national educational standards, diversification of educational models and improvement of teaching technologies. At the same time each nation strives to enrich its historically developed educational potential by actively studying the innovative experience of organizing and maintaining the education of other countries.

It should be noted that professional education occupies a central place in the new paradigm, since it is precisely this education sector that is entrusted with the task of giving all citizens the opportunity to master the necessary skills and competencies. In addition special attention is paid to improving an access to professional education for the poor and socially vulnerable groups, as well as for those who previously had no opportunity to get an education. For many centuries various forms of organization of higher education have been and continue to evolve.

Analysis of relevant reserch. The analysis of psychological and pedagogical literature shows that the significant contribution to the development of the problem of pedagogical education in foreign countries has been made by well-known domestic scientists, namely: I. Zyazyun, N. Lavrichenko, M. Leshchenko, E. Matvienko, N. Mukan, E. Ogienko, L. Pukhovskaya, A. Sbrueva and others.

Among foreign researchers, the problems of pedagogical education have been studied by D. L. Clark, L. Darling-Hammond, L. Fischer, C.J. Graddy, M. Hunter, E. F. Iwanicki, J.Kelly, D.C. Lortie, M.S.Lewis, G. Madaus, T. McGreal, R.F. McNergney, J. Millman, M.A. Rebell, L.M. Rudner, D. Schimmel, M. Scriven, L.A. Shepard, B. Shimberg, L.S. Shulman and others.

We focus attention on the fact that at the present stage of the development of education some aspects of the teacher training system in the UK, Canada and the USA have been analyzed, but not completely. Therefore, we want to turn to the study of various forms of higher pedagogical education.

The aim of the article is to find out the fundamentally modern models of pedagogical education in Great Britain, Canada and the USA; to determine the peculiarities and characteristics of modern models of pedagogical education in the mentioned countries.

Materials and methods. To achieve this aim a set of interrelated methods has been used: general scientific analysis, synthesis, systematization, generalization, comparison for the definition of modern models of pedagogical education; specifically scientific - structural-logical, systematic-structural to clarify the peculiarities and the interaction between the modern models pedagogical education in Great Britain, Canada and the USA.

Results and their discussion. We consider it appropriate to pay attention to the forms of organization of higher pedagogical education of Great Britain, Canada and the United States in this article. The choice of the three countries is determined by the desire to explore and draw a parallel between the trends according to which the professional development of teachers is realized, on the one hand, in the UK as the subject of the European educational space, and on the other hand, the trends which characterize Canada and the United States, where the contextual and procedural features are similar. These countries have significant pedagogical achievements and a developed system of continuous pedagogical education, in the context of which the professional development of teachers of general education schools is realized, and its theory and practice is determined by historical development, social progress, national traditions and takes into account the peculiarities of the international educational space. These are highly developed countries that make significant investments in the development of the education system, seeing in this as ensuring the guarantee of social stability, improving the well-being of citizens and the country as a whole.

In the last decades there has been of growing interest in training teachers in Great Britain which shows differences with the educational systems of continental Europe. As a rule they pass from a kind of «Napoleonic», from top to bottom [9] to more decentralized models, where schools and teachers tend to become more autonomous. In England in the 1970-s another and substantially opposite process occurred [12]. The English school moved from a very large educational autonomy to strict control by the center [10], gaining more autonomy in managing economic resources [7]. 
Until the seventies of the twentieth century the main objects of education in England were agriculture, personal growth, diversity and freedom for teachers and students [7]; there was no national curriculum, and teachers enjoyed greater autonomy compared to their continental counterparts. Training of teachers took place in universities, polytechnic schools or colleges of education.

Since the 1970-s, the doubts have arisen about the appropriateness of this situation, and in 1988 the National Curriculum was promulgated. In 1984 the Council for the Accreditation of Teacher Education (CATE) established a general curriculum for teacher training, which significantly reduced the weight of «educational» subjects (pedagogy, psychology, sociology and so on). CATE was abolished in 1994 and replaced by the Teacher Training Agency (TTA), whose clear goal was to move from teacher education to teacher training. [8] After that pedagogical education became more practical and disciplined and less educated [11].

In the UK a consistent model is the most common direction for teachers of secondary education. From the late 1980 -s to the early 1990 -s a number of alternative routes to qualified teacher status, time and employment were available in England [5, p. 13].

This rather radical change had the following objectives $[7 ; 6]$ :

- to register and test the teaching and learning of basic knowledge;

- to reduce the impact of universities on the education of teachers through other training programs to access the assignment;

- to have a suitable staff of teachers for effective implementation of the assigned tasks.

As a result of the analysis of scientific literature we can present modern models of teacher education in England.

1. Undergraduate teacher training (BEd). BEd is a training program that leads to QTS. It can last from three to four years in the case of full-time education and from four to six on a part-time basis. It is intended primarily for primary school, but is also suitable for secondary education. During the attendance teaching is provided for. If students have other student credits, the duration of the curriculum may be shorter. Bachelor of Arts (BA) and Bachelor of Science (Bachelor of Science) with QTS are practically similar to BEd, but the studies are more focused on disciplinary subjects. These curricula also lead to QTS.

2. Postgraduate training of teachers. It is Postgraduate Education in Education (PGCE). This curriculum is designed to develop the teaching skills of students with a bachelor's degree or equivalent degree and is designed primarily for high school. The duration of study is one year full-time or two-year part-time.

3. Primary training of primary school-oriented teachers (SCITT). SCITT, which is offered by consortia of schools and colleges on the basis of their needs, appeals to graduate students wishing to complete their education in the educational environment. Teaching is transmitted by experienced teachers. This leads to QTS, and in some cases to PGCE. Its duration is one year full-time.

4. The programme «Teach first», guided by independent organizations, is clearly addressed to «leaders tomorrow». This allows those who have «excellent» degrees to work for two years in high-level schools in London, Manchester and the Midlands to get QTS and develop management and leadership skills.

5. Employability classes in the field of employment. The Graduate Teaching Program (GTP) is a form of onthe-job training, allowing graduates to become teachers at work. Its main goal is to involve mature people who want to become teachers, and this is very much in demand nowadays. During training, which lasts from three months to a year, depending on the previous experience, candidates work as unskilled teachers.

6. Registered Teachers Program (RTP). Those who have not completed their academic studies, but have the equivalent of 240 credit accumulation and transfer points (CATS), can complete their studies and qualify for teachers. It also targets those who, in another profession, want to become a teacher, but cannot afford an academic fulltime academic program. To participate, candidates must work as unskilled teachers in the school for a period of one to two years, depending on the previous experience.

7. Training of teachers based on evaluation. It is status of a qualified teacher. Anyone who has a diploma and worked as an instructor or an unqualified teacher for a certain number of years in English schools can apply for QTS based on the compliance of their skills with the standards. This is done by submitting a portfolio to the University of Gloucestershire, which is responsible for accreditation, including one on-site audit and lasts up to one year.

8. Foreign prepared pedagogical program. EU teachers are on par with the English; teachers from non-EU countries can carry out a special qualification program that provides for individual procedures, as appropriate. It should be emphasized that in England there is a shortage of teachers in some disciplines, and the appeal to foreigners is consistent [9].

Thus, the analysis of scientific literature has shown the existence of various models of teaching training in Great Britain which are of great demand among the students.

Of particular interest to the national pedagogical science and practice is the Canadian system of continuous pedagogical education as the process of training and retraining the teaching staff of this multinational country accumulates the experience of different nations in relation to the organization of the educational process using modern innovative technologies [3].

Historically a unique system of continuous pedagogical education has been formed in this country. Each of the 10 Canadian provinces and 3 territories has a special right to pass its own laws on the development of teacher education. The structure of education is determined by the laws of the provinces, the Ministry of Education and in some provinces by the councils of schools.

In Canada, there are two main structural models of teacher education:

- a synchronous model or parallel (a combination of subject and professional training in the general course of higher education);

- a consistent model (the implementation of the professional training of teachers at the completion of the course of higher education in a specific subject area) [3].

To obtain the qualification of a teacher and the right to teach in educational institutions in Canada, you must have 
a bachelor's (or master's) degree in education, as well as a document confirming the qualification in the field of a specific academic discipline. The types of diplomas and certificates in different provinces vary. In most provinces diplomas are considered temporary for 2-5 years. Temporary diplomas become permanent after several years of successful work. In addition, to get a job requires a teacher's certificate of the province.

In addition, in Canada the problem of access to pedagogical education for a wide variety of people, including representatives of indigenous nations and occupying an unfavorable economic position in society, is being successfully addressed. Special programs have been opened for the training of indigenous teachers, programs for residents of remote regions of the country, which provide a unique opportunity to receive pedagogical education on the job without having to go to study to the central universities. An example of this is the teaching program of Western Kutaniya (rural area of British Columbia). The program was founded in 1990 as a part of the provincial initiative in the policy of providing an equal access to university education in British Columbia. Since that time it has offered three main programs: a 12-month primary education program, a 12-month secondary education program and a 24-month elective primary education program. The program has been created in order to meet two main objectives:

- to provide an access to teacher education for those students who could not enter the university in Vancouver or Victoria;

- to provide teacher training for Kutaniya and other rural regions. About $70 \%$ of students in this program are from the Kutanian region, the remaining $30 \%$ are from neighboring rural areas [2].

It is necessary to stress that there is no wide diversification in the system of training teachers in Canada due to its specific location, division and historical backgrounds.

Speaking about the pedagogical education in the US, we should mention that it is obtained in colleges, institutes and universities. The system, as for other specialties, is three-level: bachelor's, master's and doctoral studies. There are several models of training teachers. Professional training of future teachers in the USA universities is carried out in parallel, consistent and alternative models. The parallel learning model usually includes four years of full-time teacher training and leads to a first-degree bachelor of education. The successive model of training in the USA includes three to four years of study in the subject (or subjects) of the specialization of the future teacher, after which he/she receives the first degree and the subsequent one-year vocational and pedagogical training leading to the second degree - the certificate of com- pletion of the course on education after university. Alternative ways to obtain the status of a qualified teacher include the following models: a contract teacher training scheme; a scheme of licensed training of teachers; school centers for the initial teacher training.

Over the past few years an integrative teacher training model has been implemented at the University of Texas at El Paso [4]. Its main elements are: - integration of theory and practice in teacher training; - block teacher training program; - a team approach to the integration of the content, methods and forms of teacher training; - formation of the teacher's experience through the development of constructive pedagogical thinking; - professional portfolio as an integrative tool for assessing the level of teacher training.

At the present time the education system in the USA is undergoing global changes: following the rapid development of modern technology, America is preparing a new generation of professional educators online. Now you can get a diploma of a specialist in pedagogy for maximum of two years, without even appearing in an educational institution. Innovation is so fond of Americans that interactive online universities are opening in the country. According to the data of the US Department of Education, in 2010 the pedagogical staff of the six most successful educational institutions of the country were the teachers who received a virtual express education. In some states, such as Colorado, virtual universities (21-st Century Virtual Academy and Solodio Virtual Academy (SOVA)) operate on the bases of state educational institutions [1].

In any American university additional courses are also provided that help improve professional skills. They put speech, tell modern methods of teaching and teach different approaches to the child and psychological techniques. Thus, the system of training teachers in the USA is mainly traditional for the exception of implementing innovative forms of studying such as online education.

The conclusions. As the analysis of the scientific literature has shown, various models for the professional training of teachers are created and continue to be created in different countries of the world, whose task is to improve the quality of teacher training, the formation in them of the need for lifelong continuous education, the mastery of teachers, the necessary competences (key, basic, special) and, as a result, the achievement of high quality of educational activities in relation to the consumers of the relevant services.

In the future it seems reasonable to study and compare the curriculum of training of teachers in these countries in order to master the national system of teachers' professional training.

\section{ЛИТЕРАТУРА}

1. Баскаев, Р. М. (2008). О некоторых моделях профессиональной подготовки учителей в разных странах. Режим доступу: http://jurnal.org/articles/2008/ped9.html.

2. Волосович, Л. В. Профессиональная подготовка и повышение квалификации учителей в Канаде. Режим доступу: http://www.vestnik-mgou.ru/Articles/Doc/1929.

3. Дюжакова, М. В. Современные реформы высшего педагогического образования США. Режим доступу: http://www.dissercat.com/content/sovremennoe-sostoyanie-i-

tendentsii-razvitiya-sistemy-nepreryvnogopedagogicheskogo-obrazova\#ixzz5Dcs9eTBU.

4. Blake, S., Pacheco, A., Tchoshanov, M., et al. (2003). Keeping the whole village together: Sharing responsibility for the learning of all students. National Forum of Teacher Education Journal. Vol. 13 (1), 43-52.

5. Eurydice (2002). The Teaching Profession in Europe: Profile, Trends and Concerns. Report 1: Initial Training and Transition to Working Life. Key Topics in Education in Europe, Vol. 3 . 
6. Furlong, J. (2005). New Labour and teacher education: the end of an era. Oxford Review of Education, 31, pp. 119-134.

7. Halstead, V. (2003). Teacher education in England: analysing change through scenario thinking. European Journal of Teacher Education, 26, pp. 63-75.

8. Moon, B. (2003). Teacher education in England: current models and new developments. In: B. Moon, L. Vlasceanu \& L. Barrows (Eds). Institutional Approaches to Teacher Education within Higher Education in Europe: Current Models and New Development. Bucharest: UNESCO-CEPES.

9. Ostinelli, G. (2009). Teacher Education in Italy, Germany, England, Sweden and Finland. European Journal of Education, Vol. 44, No. 2, Part II.
10. Sayer, J. (2006). European perspectives of teacher education and training. Comparative Education, 42, pp. 63-75.

11. Stephens, P., Tønnessen, F. \& Kyriacou, C. (2004). Teacher training and teacher education in England and Norway: a comparative study of policy goals. Comparative Education, 40, pp. 109-130.

12. Vulliamy, G., Kimonen, E., Nevalainen, R. \& Webb, R. (1997). Teacher identity and curriculum change: a comparative case-study analysis of small schools in England and Finland. Comparative Education, 33, pp. 97-115.

\section{REFERENCES}

1. Baskaev, R. M. (2008). On some models of teacher training in different countries. Retrieved from: http://jurnal.org/articles/2008/ped9.html.

2. Volosovich, L. V. Vocational training and professional development of teachers in Canada. Retrieved from: http://www.vestnik-mgou.ru/Articles/Doc/1929.

3. Dyuzhakova, M. V. Modern reforms of the higher pedagogical education of the USA. Retrieved from: http://www.dissercat.com/content/sovremennoe-sostoyanie-itendentsii-razvitiya-sistemy-nepreryvnogopedagogicheskogo-obrazova\#ixzz5Dcs9eTBU.

\section{Современные модели педагогического образования Великобритании, Канады и США}

\section{Ж. Чернякова, И. Чистякова}

Аннотация. В статье рассматривается проблема развития педагогического образования в зарубежных странах. Представлен анализ современных моделей педагогического образования в Великобритании, Канаде и США. Выделены особенности современных моделей педагогического образования. Модели подготовки бакалавров, последипломного обучения учителей, последипломного образования, образования учителей начальной школы, занятия в сфере трудоустройства, программы обучения выпускников, программы зарегистрированных учителей, подготовки учителей, основанных на оценке, зарубежные педагогические программы Великобритания схарактеризованы. Проанализированы синхронные, последовательные модели педагогического образования Канады. Рассматриваются параллельные, последовательные и альтернативные модели профессиональной подготовки будущих учителей США.

Ключевые слова: образовательная система, педагогическое образование, модель, Великобритания, Канада, США. 